\title{
簡 訊
}

\section{國內 之 部}

\section{1 中國科學工作者協會宣告結束}

中國科學工作都協會 (簡称科協) 於一九四五年在

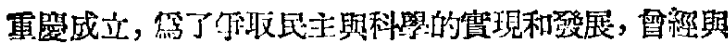

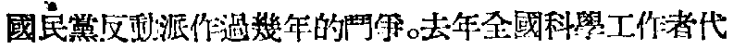
表大會的唋備，它是發起者之一。上月中旬全國科學工

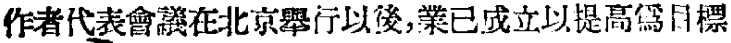

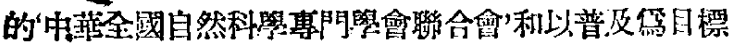

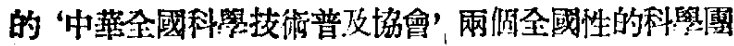

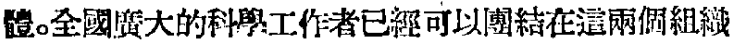

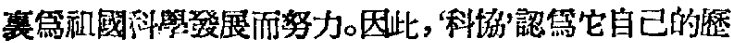

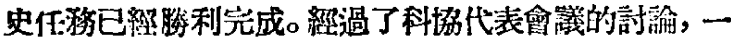

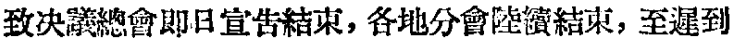
本年底煘止。

(新䔦呫稿)

\section{2 中國紅十字會改組}

中國红十字會總会已贯行改組。中央湢生部和中國

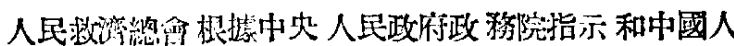

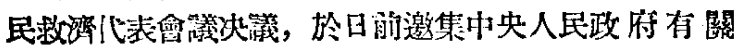

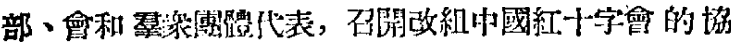
初會議，成立了新的中國紅十字會總會理事會。出片者 計有中央人民 政府衛生部、內務部、外交部、民族事移 委員會、萁僑事務委員會、人民革命軍事委員會衛生 部、北京市人民政府、中國人民救浫德會、全國總工會、 全國婦聯、全國青聯、全國文聯及原中國紅十一字會螕會 等單位代裴共二十名。

会籊首先㙏取了备方面報告後, 即討諭新中國紅十 字會總命會音草案。全體代表 對該草案原則.1:一致 通 過,最後潠出中圂紅十字會總會新理事會的理事二十七 名。

新理事會丵已舉行了第一次全澧會燨,推潠杂德全

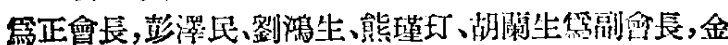

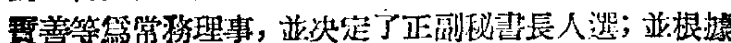

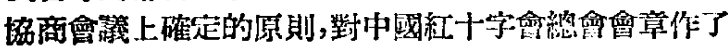
女字上的修改。

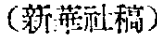

3 街生部派曲正、洪式䦓兩代 表出席捷克第六屆微生物悬 大會

揵克微生物照會决定於九月二十四日 在布拉格召 開揵克第六㖤微生物量大會, 我中央人民政泭衛生部應
揵克衙生部的邀請,已派西北軍政委員會衛生部間部辰 曲正，與浙江省立徛纵實驗院院長洪式閶兩代表於儿月 十五日晨起程前往布拉格參加該會。

（新蓞推稿）

\section{4 中央召開淮河水利會議}

國民黨反動派自將花䦭口决堤後，黄水涌入淮河， 災害速年，淮北人民遭受極大災害。中央及菲東焉了

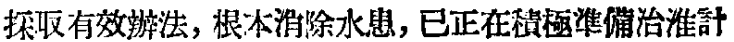

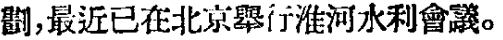

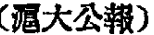

\section{5 吳度民墢明治療蛣核病新藥 '白蕉妻'}

上海現在正有一種治療結核病的新藥在研究試用。

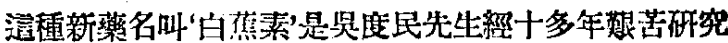

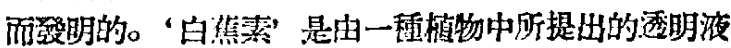

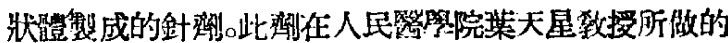

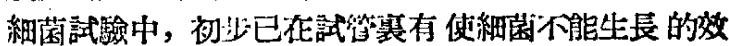

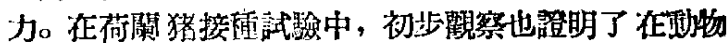

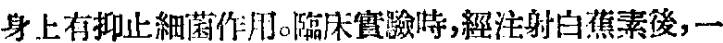
般都血沉降減低，絲度下”降，昌口轉好，體需增加。在

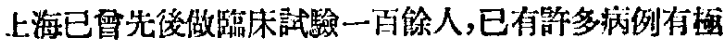

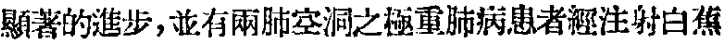

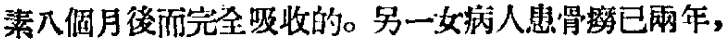
睡在石管床上,傷口已流膿,經注射白蕉素四月後,鹪口

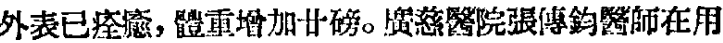
鏈徽素治祭他自己的肺病失败後，也改試用白焦素治

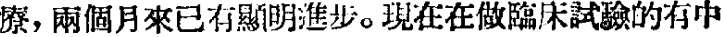

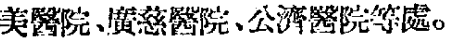

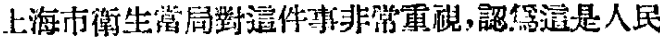

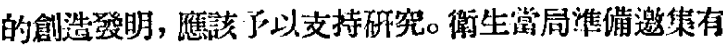

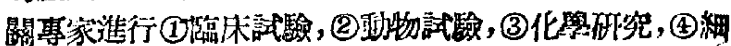

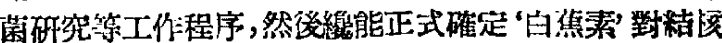
脑治潦的有效程度。

（搌大公報）

\section{6 人工送氡法}

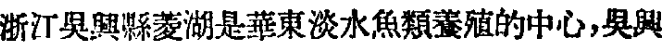

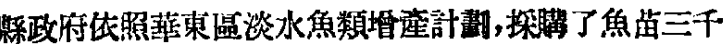
餘萬尾，於五月廿五日運抵菱湖，涂中死亡來較往年娍

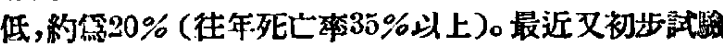




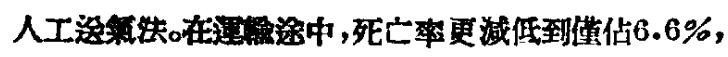

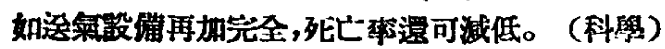

\section{7 結晶等徽素之製造}

青徽素(配尼西林)，和人民的得生健康事嶫關俰密

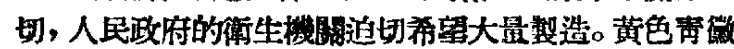
素踓能生產; 但白色結晶毒微素一直沟法提煤，而需要 的却是白色結晶青徽素。它能泊搞溫, 可以和普通藥品

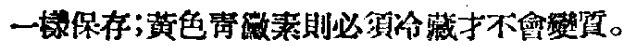

開於配尼西林結昆的研究工作，專家趙石民、汪跌、 馬繁澈諎先生已初步瓁得成積; 但是工業规模的生產方

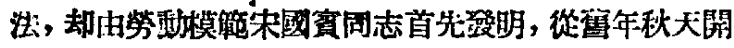
始，幾月苦心欽研，第一瓶配尼西林白色結晶，今年六

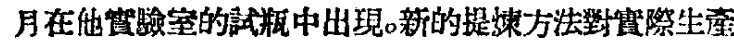

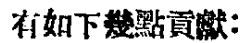

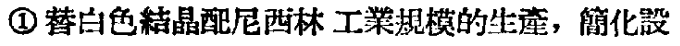

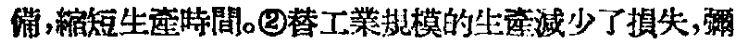

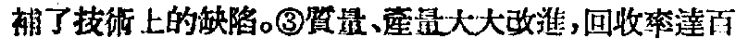

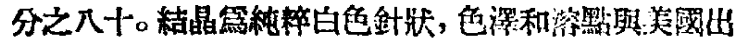
品相同。

配尼西林絬晶方法,在美國是專利品，不公開的，在

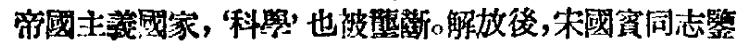
於人民衒生事業的泊切需要, 終於找到了逭張方子, 並 .日淮徜騳上将這張方子一公作。

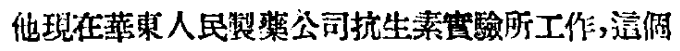

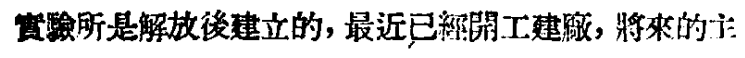
要工作就是大量製造結晶配尼酉林。

\section{（涺交襍報）}

\section{8 北京费業大學患化系製造植 物生長素成功}

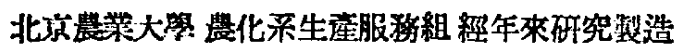
各種純粹 (C.P.)植物生長素, 已告成功。各地大燢，研

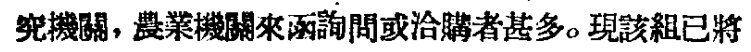

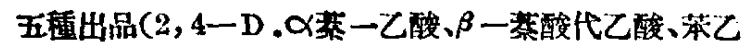
酸、苯酸代乙酸)之偪格訂定, 並印有 2,4-D之用法介 程以供參考。揬此颣植物生長素可以促淮植物生根, 防

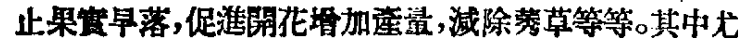

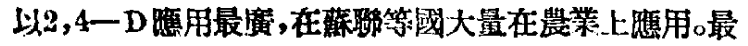

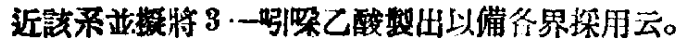

(胡策方)

\section{9 改造白煤事成功者張德鹿被 選䍃特等功臣與勞動模範}

上海公共艾通公司自去年解放以後六個月，每個月

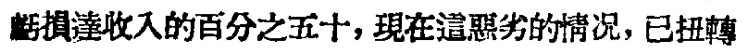

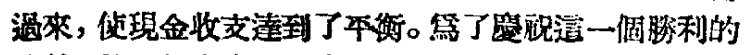

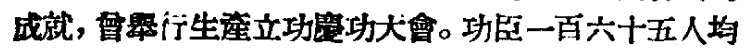
一一暂得獎賞。

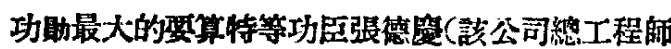

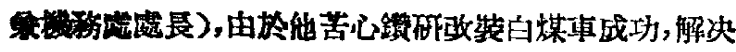

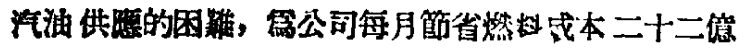

以上，使公司省定了保本自給的基礎。

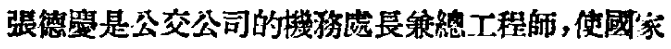

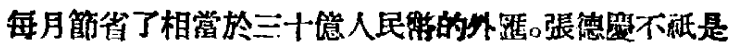
功在上海公交公司，而是功在人或國家。这指出了科照

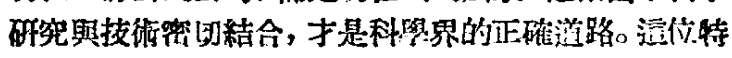
等功卢張德愛现在已被選篇.上海市政工。人一等一級篹 栜模箸。

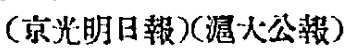

\section{0 湘江煤磄副工程師朱仲春弡 明隨進演孔鍇頭}

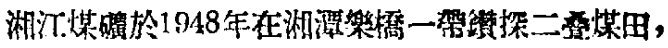

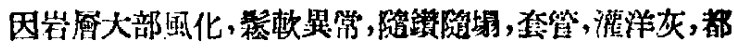

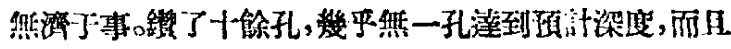

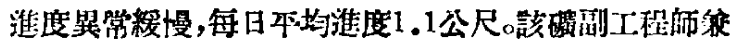

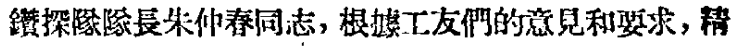

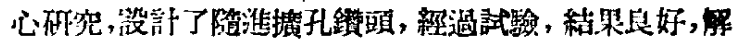

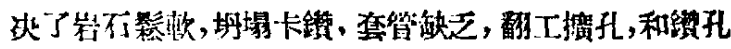

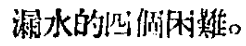

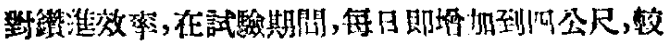

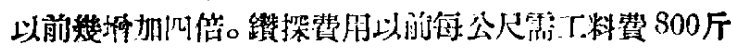

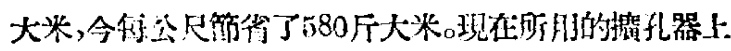

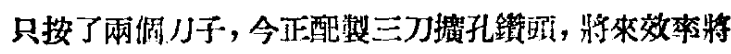

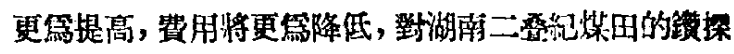
有很大的貢殿。

(中南工酷)

\section{1 荤楖煤碳機柀工人創製新工 具四種}

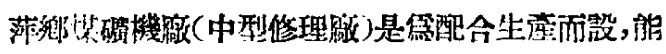

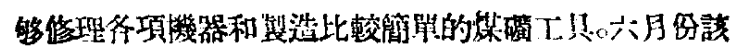

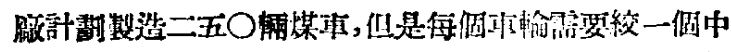

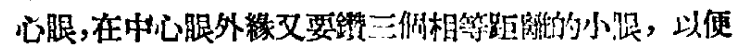

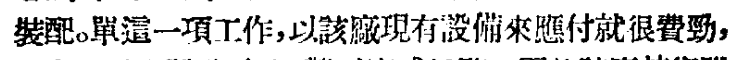

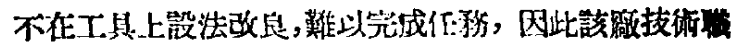

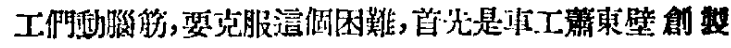

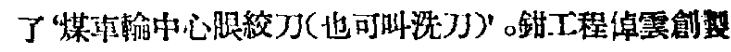

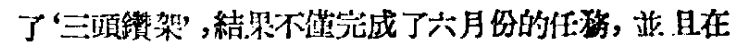
技衔創造上有了新的記錄。

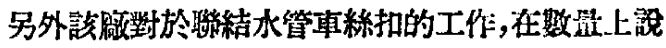

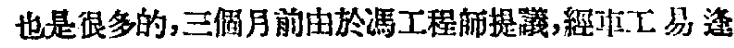
春想业了初步的工作改自方法, 後來领班管永清又作渄

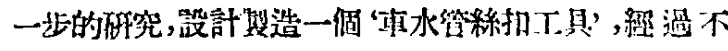

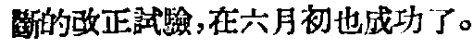

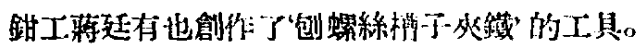

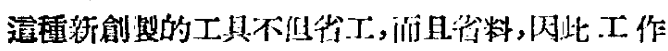

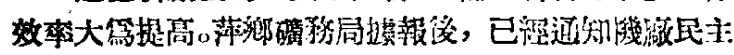

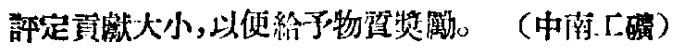

\section{2 棲霞山發現有色金屬痏}

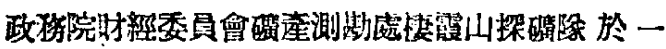

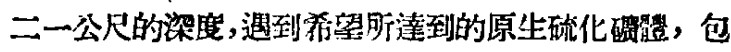

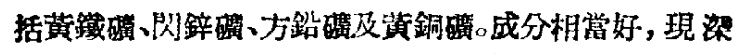

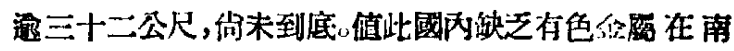




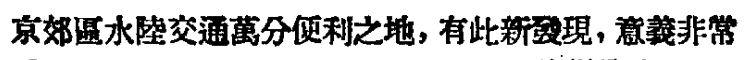
重大。

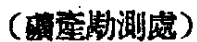

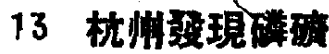

浙江省地资調查所工作同志，最近在梳州丁家山一

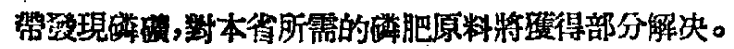

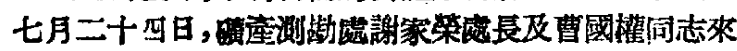
杭，浙江省地犆調查所工工作同誌即坫同至杭州丁家山铜

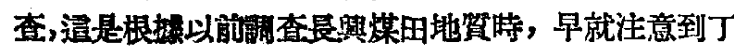

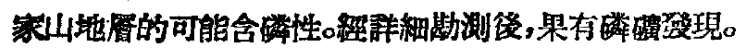

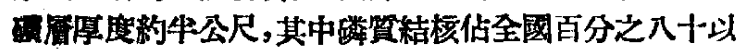

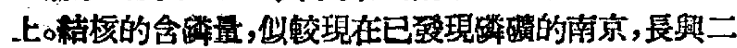

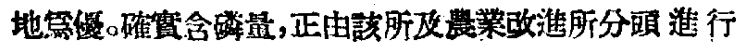
分析中。又溜過四天的普遍調查，墢現西湖附近的大零

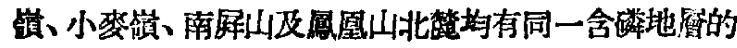
分作, 但因被草木及浮土所䔲,露頭不甚顯著,份需作適

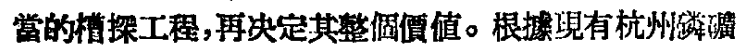

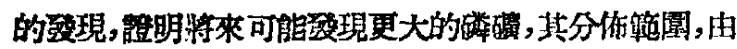
北至南可分三淢

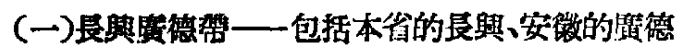
鼠江葆宜期之一部。

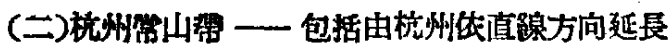

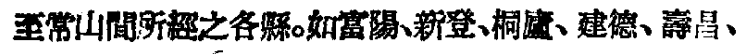
開化等箖。

（三江山能游留一包一括江山、霜州及龍游等縣, 或超長至諸繁。

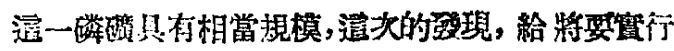

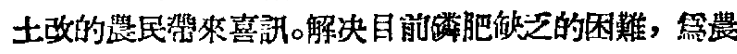

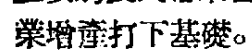

（浙江日報）

\section{4 千佛洞及敦煌文物研究所}

千佛洞㕸於比藏敦煌縣城東南二十五公里三危鳴

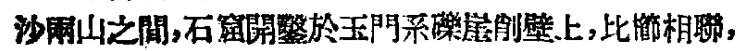

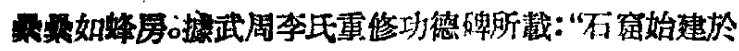
符秦建元二年”(公元三六六年)橙兩魏、隋、整、五代、

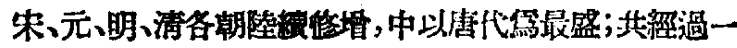
千三百四士五年，墭中国最古最重要之佛敉笜寺。

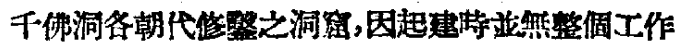

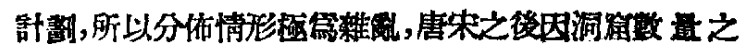

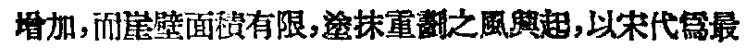
盛,各時代皆有壁畫塑像。共㖕有洞筌四二五個。其他還

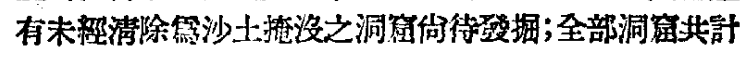
六百多倜,自南至北迤䢰1618公尺。

對於逼些窟洞負責保管和研究的是敦煌攵物研究

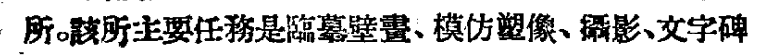
石之考古，及管理保濩石窟等工作，該所設有總務，考古 雨租, 所長是常賞沚。

去年四月南京解放绻，至河西區解放前造一弫，反

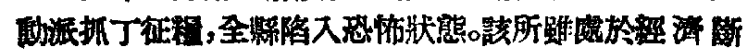

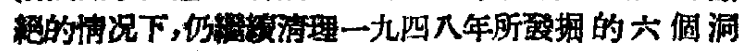
第，因方代䍃梘模過大，無法全部清理，其他大體已具规

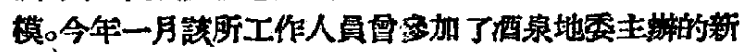

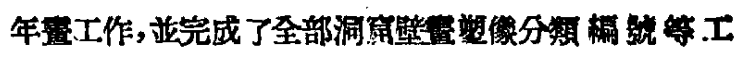

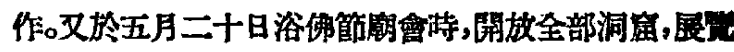
古物及所中部份工作成精。

解放後,該所已由西北軍政委員會接管，行政上由

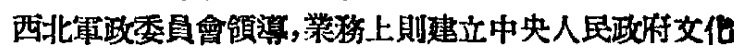

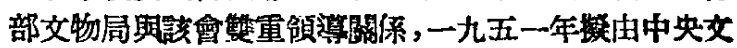
化部(通過交物局)直接領導。

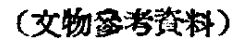

\section{5 太平天國文物一常熟報恩牌 坊碑}

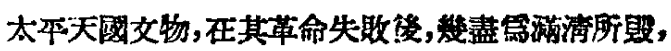

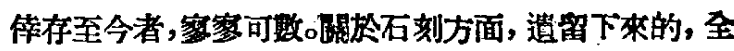
國祀有六件，常熟的報恩牌坊碑,就是其中之一。住六件 石刻中，它是內容最大的一件，全交阡三百九十一字,加 上題六字,共有三百九十七字。曼四尺六寸, 润二尺一 寸,厚六寸卅(市尺), 右上解已經断去。

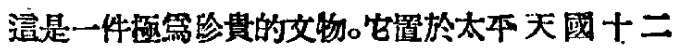
年, 即会曆一八六二年, 清同治元年, 雼常熟人民所 立。” 太平天國失敗媵，報恩牌出碑也同受摧殘，不知下落。直 到一九○九年，小祝家㓱天蹪偶然在民家發現此碑，因

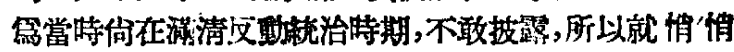

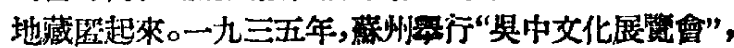

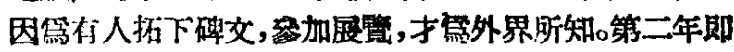

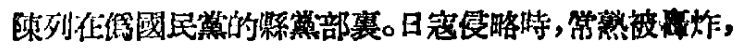
彈中给縣筧部，房舍全毁，坊碑又不知下落。一九元六年

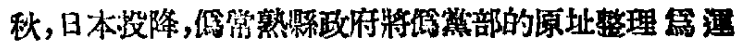
勖場持,復在無意之中發現。

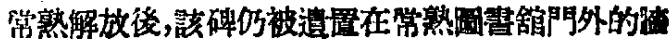
脚下，今年七月，經中央交化部交物局函請常熟市人民

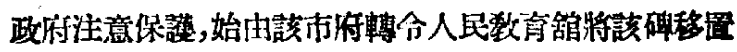

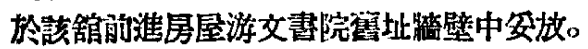

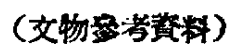

\section{6 天津市弡現大批古物}

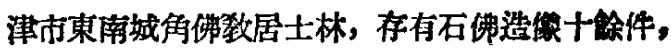

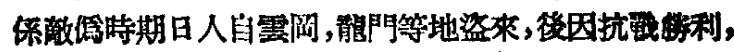

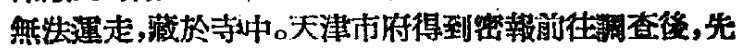
後發現六朝及唐以下各代古物一百二十餘件。其中，大 部分年代均縃鑑定，有唐代大彩色壁書一片、明代大移 色壁憲一片、明代小壁畫三十片、六朝以下大小不柳十 九座、石佛㽬及石木浮㬨三十七件、朱元磁塔石塔三件、

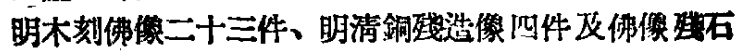
數片等。中央交化部交物局得報後，即派員前往察看，整 選定珍品:六朝浮雕、唐造像、唐代壁畫、明化木雕佛作 十二種運京陳列, 其餘將交由天津市裂術舘保存展琵。

(文物窟考不料)

\section{7 内蒙墢現巨大動物頭骨}

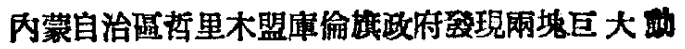
物頭骨，各約三千斤重。以 後又在庫倫街檢得一隻大牙

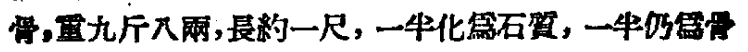




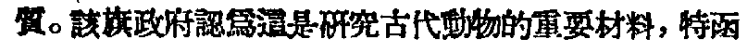

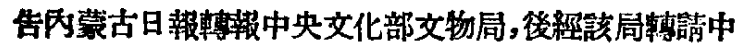

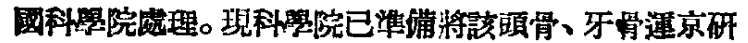
究。

（交物遗考資料）

\section{8 内寡古㜊現古生物巨角}

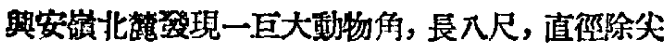

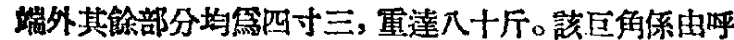

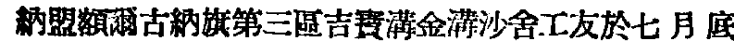
在該地㨄出,現已運至政府,淮偖由盟府轉揆 北京供 䂰究。

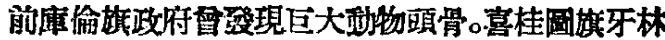

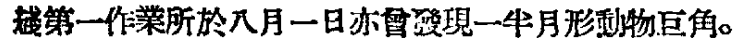

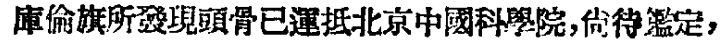

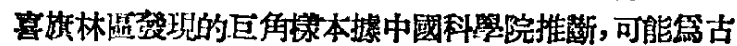
代炡之門牙,如保存完全,甚可珍貫。

(內营古日報)

\section{9 建設水力䯅電}

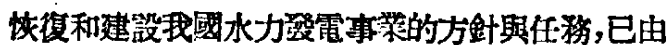
中央人民政府燃料 工業部在七月二十二日召開的全國 水電工程會锇决定。其主要內容是在今後三五年內, 配

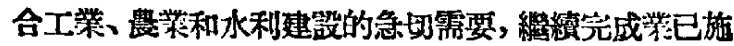

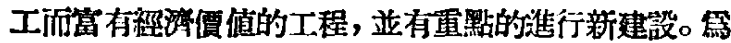
此, 水霄工程會学已確定協助地方政府、合作邧或私焒 企業倡辦小型水電事業，並堵辦農 村小型水電示範的。 首期建設重點將在太行山東槐和傸西涇渭河谷。同特，

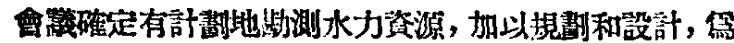
今後建設更大規模的水笔工程作潗備,按我國水力资源

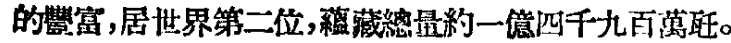
其中西南地邀佔 $65.2 \%$ 。但過去我國水力监源的開唚， 却僅及全 國蕰藏量的 $0.89 \%$ 一年以來，由於人民政府 䍌水力發電事業的重視，各地水電工程的恢復和新建工

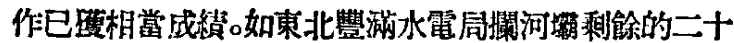
萬公方湜凝土的漟製工程，去年完成九葛公方，今年又

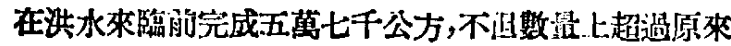

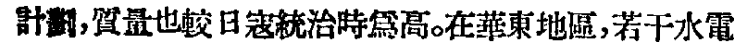
工程的修建也已完成或即將完成。

\section{（工程建鄂）}

\section{0 墨空拖架法架梁}

四月初，三位萑聯專家随德陽鐵路局郭局長到柳州

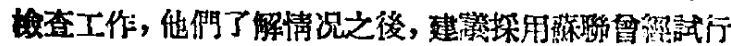

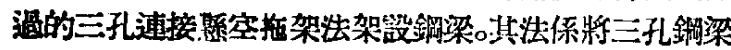

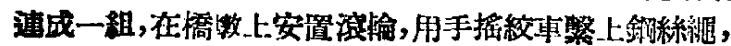

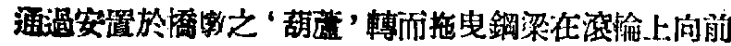

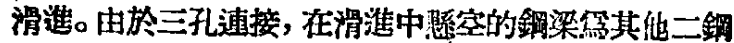
梁之重力支柱，不致掉下河中。造一建笔提出後,在工程 師和工友們之間展開了熱烈的討論。因地架法通常只用

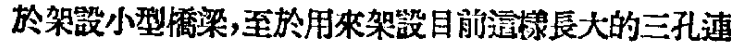
接銅梁,我國工程界還是開所未聞的。最後,大家終於战 出堔用此法的继點 一、省工、省時、省木料; 二、不需姴

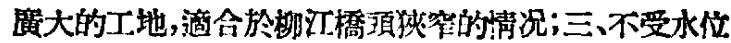

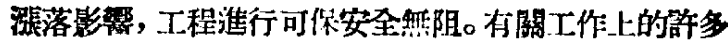

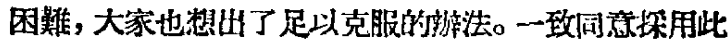

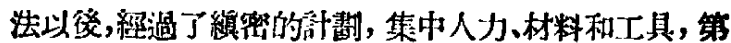

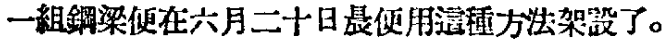

\section{（渥大公報）}

\section{1 成䞔鐵路順利鋪軌}

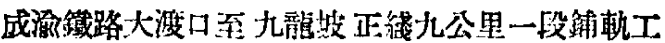
程, 自八月六日正式開始, 迄至二十五日已鋪過了九龍

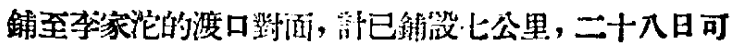

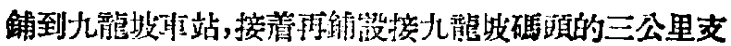

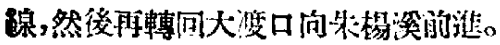

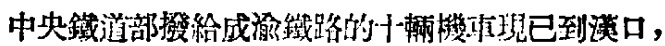

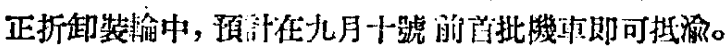

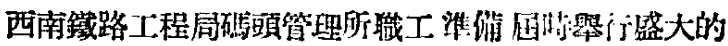

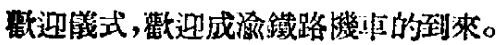

（涺大公報）

\section{2 北满地質鏣産調查除}

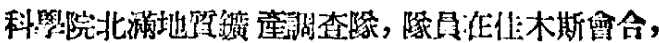

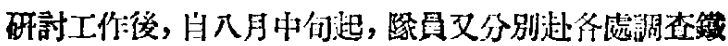

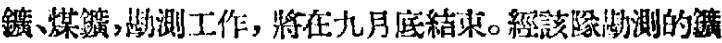

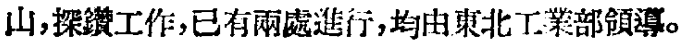

\section{（本院每摁工作䇴趣）}

\section{3 紫金山天文台修理望遠鏡}

紫金山天文台修理二十四吋返光遠镜之大嗄项及

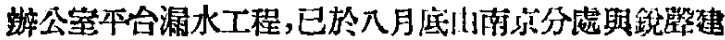

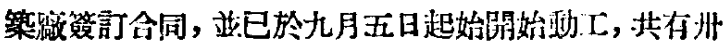
餘工人,約四十天可以完成。

$$
\text { （本院每透工作:澺赫） }
$$

\section{4 北京鼓樓冒烟}

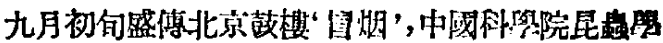

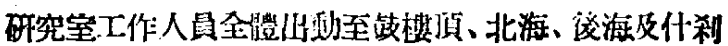

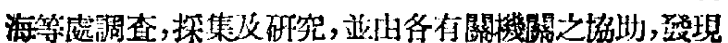

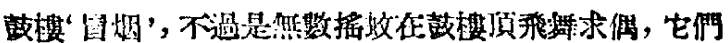

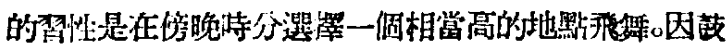

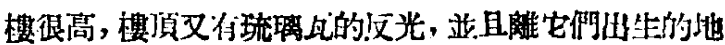

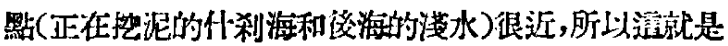

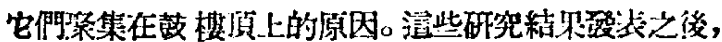

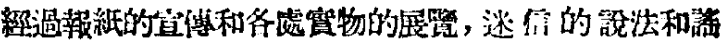

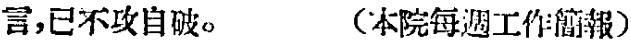

\section{5 東北輁業科學研究所在其推当 區舉行田間參觀會}

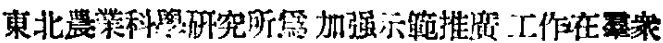

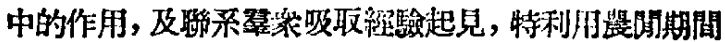

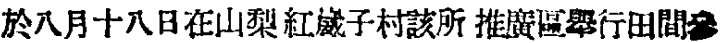

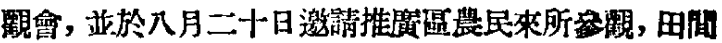

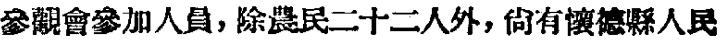


政府及村政府人員寥加。在淮行參倠之前，首由該所技

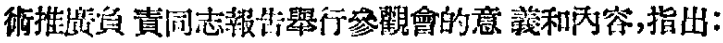
此次參貺會着重介紹理子消毒的效果,及用新式㖘具播 種大豆敋子等示範情况。在種子消毒方面，高梁種子縃

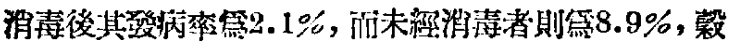

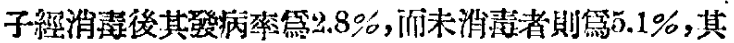

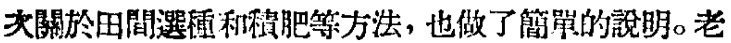

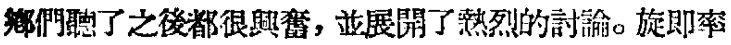

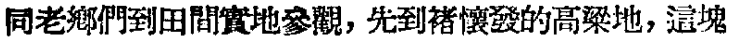
地㮔的是推庴品種紅棒子, 並且已消表, 和他自己品種 而末消毒的比䎧，一邊是鮮紅紅的，一邊是黑糊糊的，對

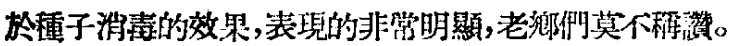

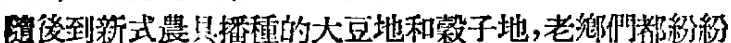

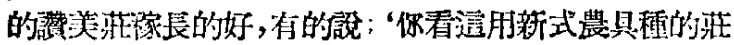
榢長的多麼茂盛啊!' 又行的說: ‘豐地黄大豆長的倶好,

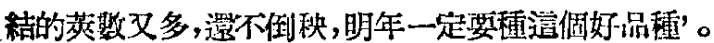

（農業挍術通訊）

\section{6 䔵州大學慶祝國慶篩皘極䇺開 展锚會}

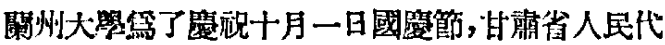
表大會開幕，闎州市中菻反好協會成立一避年，招待復 員軍人，迎接本校新老師同學到校及工會成立的五大喜 事, 定任十月一、二、三日三天開全校性的展覺會, 招待

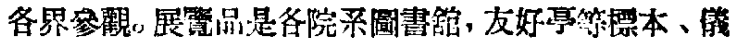

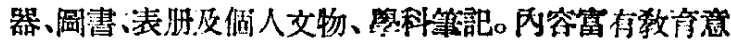

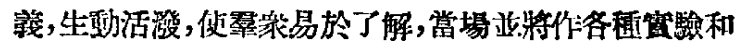

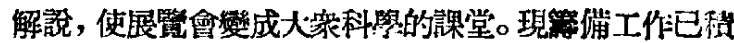

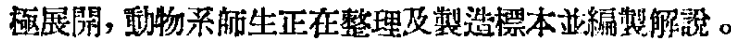

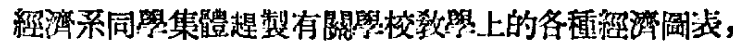
少数民族語文系師生已着手舁繪存關民族政策的漢、

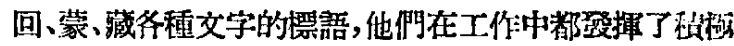
性和創造性。

（閔州大學通訊）

\section{7 三名返國数授及學生途經日本 被扣}

因不堪美國政附緊迫而返回祖國的我國留美祭生，

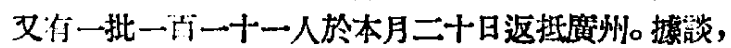

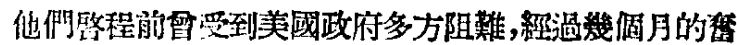

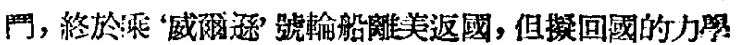

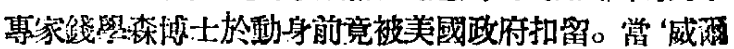

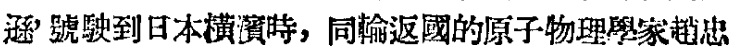

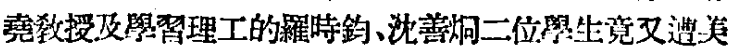

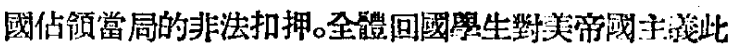
種暴行極婊慎概。他們抵稳後發表了告同胞書, 除將.. 浦情况報告中央人民政府外，並向美國國務院提出臂重 抗㩘。

（新菲补稿）

\section{國 外 之 部}

\section{1 新工作母機}

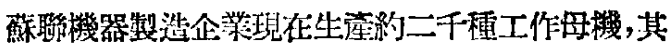
中有四分之三是蘇聯專家在戰後数年內設計的。莫斯科

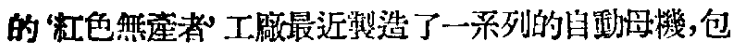

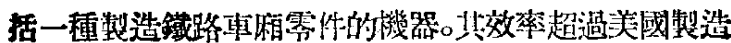

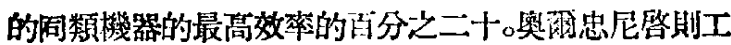

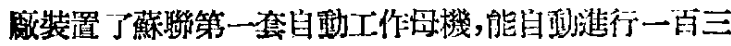

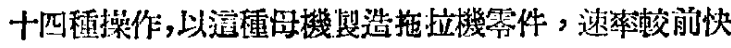
五十倍。

(新菲刑稿)

\section{2 模錅石機}

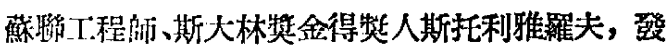
明了一種效力强大的新繁存機, 使大理石破及其他岩石 的開探過程完全機械化。新機器只要一個工人管理, 就

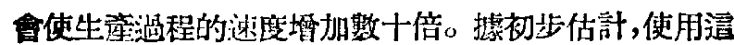
重新機器將使大理不的生產成本減少百分之四十。

（新耛社稿）

\section{3 新式探煤聯合機}

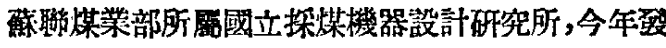
明了网種新式探煤聯合機。一喠用來開堔狹煤層, 另一

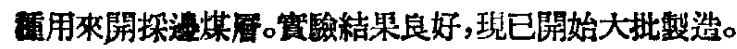
（新華社稿）

\section{4 血液凝固時間的測定}

歷來各種血液凝固率测定方法不够簡易,最近開始

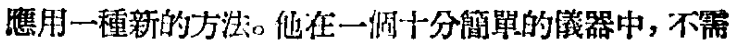
任何外面的額外機械性作用察行检查血液。

血液接照常例取自指尖。事解用毛袖玻琌涺管吸取

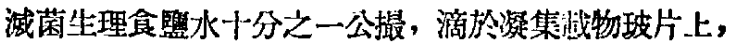

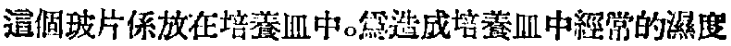
起見, 把一張用水浸瀿的吸水紨或紗布羁於底部。生理

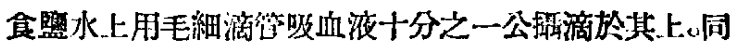

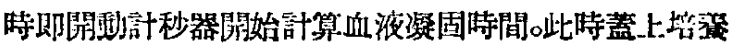
佂的罩。

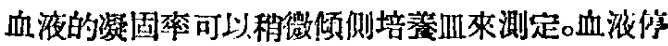

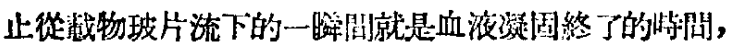

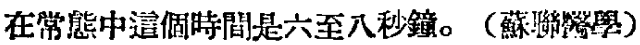

\section{5 冬季中的日光療法}

冬季中太陽光䄉落到地 本面上場合的放射力微弱

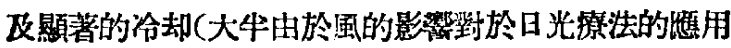

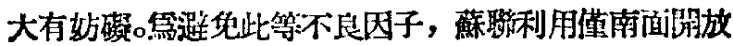
的玻璃陽合。在陽台咅面，氣溫通常比露天高出知多，湍

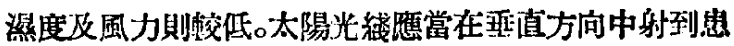

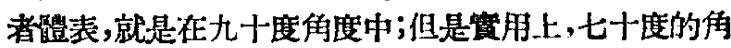

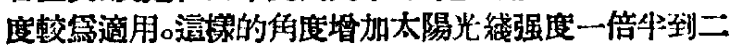

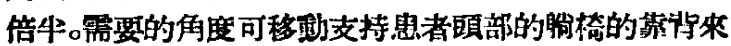

第六期

科學通報 